\title{
Low road or high road? The post-crisis trajectory of Irish activation
}

\author{
MARY P. MURPH Y
}

Maynooth University, Ireland

\begin{abstract}
Comparatively slow in adopting any clear activation strategy, postcrisis Ireland crossed the Rubicon and rapidly took steps to implement a work-first labour activation strategy. The article maps and examines the interaction of three variables - ideational influences, political interests and institutional processes - to assess the nature of post-crisis Irish activation policy. Troika imposition of aid conditionality, the ideational role of the OECD and domestic elites worked to shift the focus of Irish activation policy and its implementation. Post-crisis Irish activation is less influenced by social democratic versions of high-road activation than neo-liberal managerial stock management and conservative behavioural controls. These converge into a low-road model of activation. There is some demand for, but little articulation of, an alternative policy that could be centred around less conditionality and more focus on demandside issues including low pay, quality work, distribution of employment and removal of barriers to employment.
\end{abstract}

\section{Key words}

activation, Europeanisation, Ireland, politics, post-crisis 


\section{Introduction}

Ireland is rarely considered for the study of activation or broader comparative welfare regime analysis. However, the severity of the Irish crisis makes it an ideal and timely test case for posing the general question as to how crisis impacts on activation regimes. Pre-crisis Ireland was an exemplar competition state that subordinated social policy to the imperatives of international competition (Kirby and Murphy, 2011). Given Ireland's traditionally low welfare effort and significant level of market provision of welfare we might have expected Ireland to be a leader in work-first type activation that commodifies non-employed people and makes them reliant on the market. However, this was not the case. Ireland is generally regarded as an outlier with an underdeveloped activation practice relative to other liberal states or the European Union (EU) norm (NESC, 2011).

Martin (2014) observed how crisis in Europe triggered a new wave of reforms including curtailment of benefits and/or activation services to minimum income recipients (Portugal, Netherlands, Czech Republic) and, in parallel, a further deepening of the focus on work-conditionality (UK and Norway). This article examines whether and how crisis was used as an opportunity to converge Irish activation with European norms. We begin by briefly contextualising the Irish crisis. The next section locates the article in critical political economy approaches that understand activation as a way of managing the social and political reality of unemployment in neo-liberal political economies. We then introduce a theoretical framework that explains change as the interaction of three variables - institutional processes, political interests and ideational influences - and specifically examine literature theorising Europeanisation and international influences. We apply this framework to explain the post-crisis trajectory of Irish activation policy by first sketching the broad institutional framework guiding such policy, and then introducing the key interests who shaped this policy. We then analyse recent policy changes under three broad ideational frameworks - neo-liberal, conservative and social democratic. The conclusion focuses on how the Troika imposition of aid conditionality and the ideational role of the OECD interacted with domestic elites to shift the focus of Irish activation policy and ensure its speedy implementation. The departure of the Troika makes domestic politics and tensions more visible. It remains to be seen how the confluence of international drivers and post-2016 domestic electoral and social politics will influence Irish activation policy.

\section{Crisis}

Clasen et al. (2012) argue that the crisis triggered three different types of labour market responses across Europe: demand shock, fiscal emergency 
and structural reform. From 2007 Ireland experienced three stages of crisis: the early-crisis period 2008-2010, the mid-crisis or Troika period of 2011-2014 and the late-crisis or post-Troika period 2014-present. Despite recent economic growth and reducing unemployment, Ireland has not necessarily entered a post-crisis period; rather the terms of the EU Stability and Growth Pact suggest a period of permanent austerity. Ireland proved particularly vulnerable to the impact of the international financial crisis in $2007 / 8$. Indigenous factors such as over-reliance on property-related fiscal policies, poorly regulated bank lending practices and an ill-judged 2008 guarantee to bail out Irish banks increased Irish sovereign debt to unsustainable levels. November 2010 saw the loss of Irish sovereignty to the European Commission, European Central Bank and International Monetary Fund (the Troika) whose bailout package included a Memo of Understanding (MOU) to underpin an $€ 85$ billion loan (Ireland, 2010). This MOU has been described as a blueprint for intensification of liberalisation of the economy (Hardiman and Regan, 2012).

Ireland's financial crisis also meant an economic and fiscal crisis. Seven years of austerity budgets saw $€ 30$ billion of fiscal consolidation with a 2:1 ratio of expenditure cuts over revenue gathering and significant social impacts. Over the 'Celtic Tiger' decade of high economic growth (1996-2006), previously high unemployment dropped steadily to a low of 4.1 per cent in 2000. The crisis had immediate economic impact with a loss of over 300,000 jobs. Unemployment increased from 4.4 per cent in 2008 to a high of 15.1 per cent in 2012. More recently it has fallen to its present level of 8.8 per cent in December 2015, 54 per cent of whom are long-term unemployed. This level of post-crisis unemployment does not include over 85,000 on Active Labour Market Programmes (ALMPs), 115,500 underemployed workers and the 70,000+ per annum who emigrated over 2011-2014 (Figure 1) (CSO, 2014, 2015; NERI, 2015).

Pre-crisis, the basic features of the Irish welfare state were largely consistent with liberal welfare regimes albeit Ireland had a more generous level of welfare payment, a relatively high level of investment in ALMPs, and less use of sanctions and conditionality than the UK or other liberal regimes (NESC, 2011). Grubb et al.'s (2009) OECD review of pre-crisis activation likened Ireland to an 'emperor who had no clothes' with much lip-service paid to activation principles but little implementation (Martin, 2014). While Ireland in 2010 had above average public spending on ALMPs ( 1 per cent of GDP compared with an OECD average of 0.65 per cent), there was little engagement with Public Employment Service (PES) clients; rather 'the Irish authorities left the unemployed to their own devices' (Martin, 2014: 16). The pre-crisis Irish activation strategy, the National Employment Action Plan (NEAP), was a requirement of the European Employment Strategy (EES) Open Method of Co-ordination (OMC) and generally regarded as lack- 


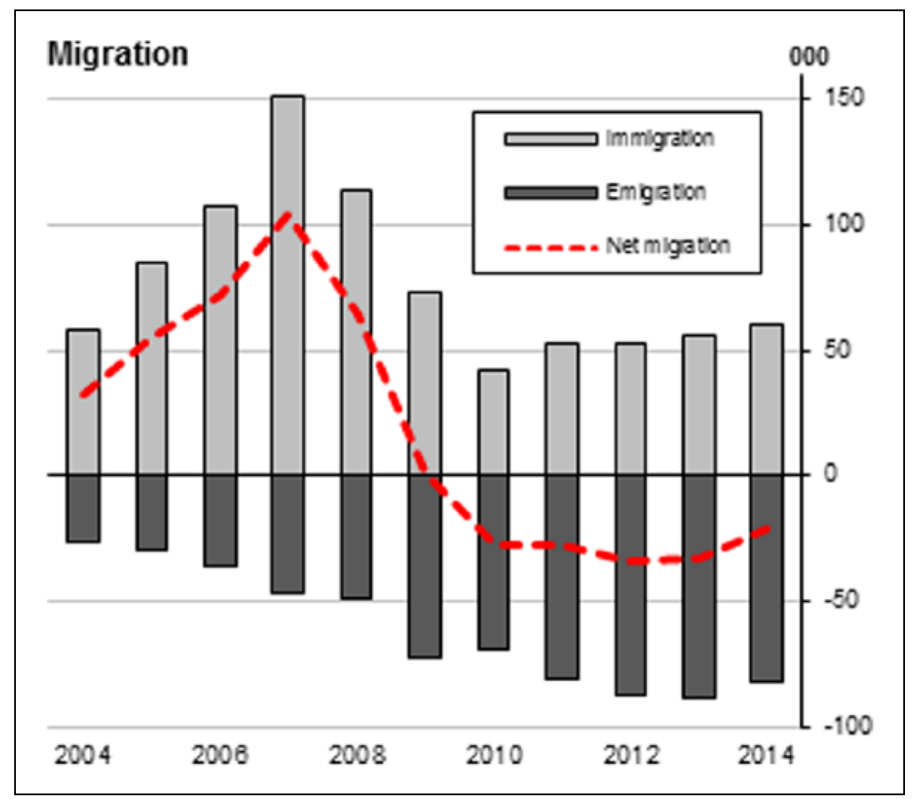

Figure 1. Net migration for Ireland 2004-2014.

Source: CSO, 2014.

lustre with little or even negative impact on employment outcomes (Forfás, 2010; McGuinness et al., 2011). Entering crisis, Ireland appeared to stand on the fulcrum of a seesaw, straddling the low road and the high road (NESC, 2011). Post-crisis, Ireland made a definitive policy choice and rapidly took significant steps to implement a new national activation strategy laid out in Pathways to Work (DSP, 2011) and a Youth Guarantee (DSP, 2014a). The key question for this article is how domestic and international ideas, interests and institutions interacted to construct this policy shift and ensure its implementation.

\section{Activation}

This section locates the article in critical debates in the wider activation literature. Brodkin (2013) identifies a 'global workfare project' which comes under different labels including welfare-to-work, welfare reform, labour market activation, jobseeker allowance and revenu minimum d'insertion; all incorporate promoting participation in the labour market and reducing cash benefits. While many use the language of activation and workfare interchangeably, Lødemel and Moreria (2014) differentiate workfare (compulsory participation in paid employment) from activation (compulsory participation in other forms 
of ALMPs including education, training, occupation, job search). While activation can be understood as a specific programme, it is better understood as a wider policy strategy of 'designing benefit rules and employment or training services with a view to moving unemployment income benefit recipients into work, and involving a wide range of interventions including fiscal policy, public services and education or training' (Lødemel and Moreria, 2014: 9). Bonoli (2013) outlines the long history of activation which originally focused on enabling active labour market programmes and regulating the job-search behaviour of the unemployed. By the mid 2000s the OECD and European Employment Guidelines approach to activation had widened to encompass 'interactions between income systems, ALMPs and benefit conditionality, as well as proactive management of employment services to effectively promote and assist the return to work' (Martin, 2014: 7).

Contemporary approaches to activation developed in the context of managing the politics of unemployment and the cost of social assistance in neo-liberal economies. As social policy became subordinated to economic imperatives, governments focused on ways to limit social assistance and manage the conduct of the unemployed through a range of enabling, regulatory and compensating packages (Brodkin and Marston, 2013). Two approaches dominate: work obligations as a condition for receiving minimum income benefits; investment in active labour market policies (ALMPs) or in-work benefits to assist recipients' return to the labour market. Early typologies of activation regimes often distinguished a European focus on human capital and decent work from a work-first US approach dominated by promoting self-reliance through paid employment. Later analysis differentiates less between the US and Europe. Both now focus on work and stress financial incentives to work, integration of benefit and employment services, and delivery or governance mechanisms associated with privatisation or marketisation.

Grover (2009) understands activation as part of the broader shift towards neo-liberal governance where social policy is subordinated to economic competitiveness. Privatisation, by giving non-employed people an economic value, commodifies people with a view to supplying capital with suitably willing workers. Following Peck and Theodore (2000) he stresses how unemployment is managed through 'supply-side fundamentalism' which goes beyond 'employability', to construct a scenario where unemployment is caused by unemployed people, where demand is ignored and where activation works to push downward pressure on wages. Darmon and Perez (2010: 84) associate activation with the recommodification of labour and capital's demand for new forms of 'floating' or more portable and flexible employees. Bengtsson (2014) uses 'standby-ability' to describe similar processes in Sweden and Demark while, in Ireland, Murphy and Loftus (2015) describe flex-insecurity and O'Sullivan et al. (2015) use the term if 
and when' to describe the reality of employment scheduling for precarious workers in Ireland.

Privatisation of employment services also shifts power and enables soft convergence through managerial reforms that undermine potentially enabling elements and intensify regulatory or punitive elements (Brodkin and Marston, 2013). This shift to market-led governance has led to more systemic co-ordination, collaboration and decentralisation (Heidenreich and Graziano, 2014), as well as increased marketisation of employment services and processes of individualisation, targeting, tailoring and one-to-one contracts or personal plans (Lødemel and Moreria, 2014). Not all countries have proceeded at the same pace; Van Berkel et al. (2012) differentiated modernisers, slow modernisers and committed marketisers. Despite recent reforms and engagement with employment services marketisation processes (Wiggan, 2015: 151), Ireland can be characterised, alongside Italy and the Czech Republic, as a slow moderniser.

\section{Theoretical framework}

New institutional scholarship (Hall and Taylor, 1996) combines culture or ideas, institutions and interests as approaches to explain regime change or stasis. Hay's (2004) approach avoids privileging one of these factors over others; rather he uses a three-dimensional framework to understand the process of change or stasis as the interaction of ideas, institutions and interests. Theoretical insights from studies of activation enable deeper understanding of recent Irish change. Ingold and Etherington (2014: 621) stress the importance of the diffusion of ideas (causal claims, beliefs and assumptions) articulated by policy actors as crucial to both the construction and delivery of activation policies. Van Gerven et al. (2014) examine 'Europeanisation' understood as domestic change caused by two types of European integration: (i) the European Employment Strategy (EES) which influences through peer review, mutual learning, targets, annual reporting and (ii) the Economic and Monetary Union (EMU) framework which influences through fiscal targets that encourage lower tax burdens and cuts in social expenditures. Crucially, as Armingeon (2007) argues, both dimensions are mediated through domestic political actors and conditioned by local labour market institutions. Van Gerven et al. (2014: 524) hypothesise that key Europeanisation mechanisms - leverage, learning and aid conditionality have greater impact in unitary centralised states. For De la Porte and Pochet (2012), the impact of Europeanisation also depends on which ministries participate in national peer review and whether unions, as social partners, participate meaningfully in such processes. Clearly, domestic actors and institutions filter international influence. 
Ireland, as a small centralised state, appears an ideal candidate for a high level of Europeanisation but pre-crisis this influence did not translate into a significant activation policy or its implementation. Using the framework of the interaction of institutions, interests and ideas to understand the trajectory of post-crisis Irish activation we explain the recent shift towards activation in the context of 'aid conditionality'. We argue the Troika period opened up the ideational significance of the OECD in a context where the Troika presence also mitigated previously strong policy inertia and domestic implementation vetoes. The Troika influence appears to have been to drive through the veto culture which might otherwise have sunk this long anticipated reform agenda (Murphy, 2012b). Troika targets and monitoring schedules challenged the Irish tendency towards 'implementation deficit disorder' (Kirby and Murphy, 2011: 62), and Troika presence ensured a fuller implementation at a faster pace than would have otherwise been the case. To illustrate this argument the following three sections use this framework of institutions, interests and ideas to map and analyse the trajectory of Irish activation during the crisis.

\section{Institutions}

One impact of the crisis is that power is now more centralised in the Irish political system (Kirby and Murphy, 2011). While, post-crisis, there had been some initiatives to strengthen parliamentary scrutiny, Troika institutional arrangements further centralised the process of policy making (Hardiman and Regan, 2012: 9). New domestic institutions included a ministry for Public Expenditure and Reform, and an Economic Management Council, comprising the four most senior government ministers (Taoiseach (Prime Minister), Tánaiste (deputy Prime Minister), Finance, and Public Expenditure and Reform). Collectively these consolidated fiscal and policy control at the centre of government.

Tsebelis (2002: 209) differentiates states according to institutional characteristics that give rise to 'veto points'. Some political systems 'are prone to crisis-engendered institutional change', others are characterised by 'incremental reformism' (Hay, 2004: 205). Multiple veto players lead to policy cultures dominated by policy avoidance, a consensus culture and a more conservative policy predisposition. The Irish electoral system combines with other veto points including a rigid constitution, a two-chamber parliament, coalition governments and social partnership to orient Irish political culture and policy making in a direction that makes path dependence more likely. This contributed to the previous slow pace of activation reform (Murphy, 2012b). Earlycrisis reforms included removal of one key institutional veto point, social partnership, while the presence of the Troika and centralisation of power diluted the impact of other veto points, notably parliamentary opposition. 
Austerity cuts also weakened or closed down key national equality and human rights institutions and many local community organisations; these losses mitigated resistance to activation reforms (Harvey, 2014).

In the early-crisis period, the pressure of rocketing unemployment prompted short-term emergency responses, welfare cuts and little institutional reform. ALMP spending per unemployed person reduced as unemployment rose and strong pressures for fiscal consolidation caused public spending reductions (Martin, 2014: 12). In 2011, under direction of the Troika MOU, the newly elected government committed in the Programme for Government (Ireland, 2011b) to develop and implement a new activation strategy that had been previously outlined in the previous government's National Recovery Plan for 2011-2014 (Ireland, 2011a). The activation strategy Pathways to Work (DSP, 2011) focused on five key action points: more regular and ongoing engagement with non-employed people; greater targeting of activation; incentivising the take-up of opportunities; incentivising employers to recruit the unemployed; reforming institutions to deliver better services. This has been updated annually (DSP, 2014b; Oireachtas, 2015). The first major midcrisis institutional reform in 2011 was to merge personnel from $F A ́ S$ (the precrisis Irish National Training and Employment Authority) and the Health Service Executive into the Department of Social Protection (DSP). This unified benefit administration and public employment services into Intreo, a 'onestop-shop model' launched in 2012. Intreo reached an ambitious 2014 target of 60 new offices (Labour Market Council, 2014: 13). Merging these institutions doubled PES institutional capacity. However, the Employment Services Officer:Claimant ratio remained high by international standards and serious capacity gaps remained (NESC, 2011). In October 2014 DSP contracted two private sector companies to provide employment services to Ireland's longterm unemployed through a new pay-by-results activation programme, 'JobPath', which became operational in 2015. In parallel large-scale institutional reforms, a new national training agency 'Solas' was established in 2013 and sixteen regional Education and Training Boards were created by merging local authority Vocational Educational Committees and local FÁS Training Centres. The scale of this unprecedented institutional reform was unlikely to have been achieved without the presence of the Troika.

\section{Interests}

Partisan politics is a crucial factor determining variation in governments' responses to crisis (Huber and Stephens, 2001). Pre-crisis domestic interests had been relatively passive and unambitious in relation to activation - shifts in domestic political power had had little impact on the trajectory of Irish activation. The Troika disturbed previously strong policy inertia and domestic 
implementation vetoes. From 2008 to 2011, the incumbent centre-right and populist Fianna Fail (FF)/Green Party (GP) coalition responded to the earlycrisis period without any significant institutional reforms or ambition. This was in spite of negative evaluations of the previous Irish activation strategy (Harmon et al., 2012; McGuinness et al., 2011), and a major corporate governance scandal in FÁS. This is consistent with historical political protection of FÁS by FF and the social partners (Boyle, 2005). Meanwhile, even in the context of significant emigration, the crisis saw unemployment increase from 4 per cent in 2008 to 15 per cent in 2010 and PES were clearly unable to meet growing demand. In 2010, under pressure, the FF/GP government committed to reform labour market institutions as a key horizontal measure of their National Recovery Plan for 2011-2014 (Ireland, 2011a). This reform agenda mirrored OECD (Grubb et al., 2009) recommendations for activation. The plan was subsequently consolidated and reinforced with targets and timetables in the Troika MOU (Ireland, 2010). The practical pressure for reform combined with the presence of the Troika shifted previous vetoes, obstacles and overall indifference to reform.

Activation was not a burning issue in the February 2011 general election, nor a negotiation barrier in the subsequent coalition formation process. A new government took power in March 2011 with Fine Gael (FG) firmly in the driving seat of a Christian/Social Democrat coalition with the Labour Party (LP). The politics of the welfare state often emerges through hidden institutional struggles in the state bureaucracy (Hacker, 2004). While the central social protection and education portfolios were held by social democratic ministers, these ministries were not at the centre of power. The workfirst activation model appears partially driven by the Labour Market Council, which meets in the Department of an Taoiseach and is chaired and populated by private enterprise. Inward recruitment from the private sector, to the most senior position of Intreo, is consistent with a more managerial culture (Brodkin, 2013). The 2014 privatisation of some PES is likely to shape future policy and implementation and lessen the remaining influence of trade unions (Lipsky, 2013). The LP presence contributed to the partial defence of some vital economic floors, including the minimum wage and informed the choice of the Irish JobPath privatisation model (Wiggan, 2015: 162). Confidence in the social democratic presence in government may have neutralised or mitigated some natural opposition to some reforms.

Late-crisis, and facing a general election in 2016, Irish citizens are electorally volatile: significant numbers of voters are 'undecided' and many are turning away from mainstream parties to independents, left alternatives or seeking new political parties. Activation policy featured in the 2014 EU election campaign in the form of LP campaigns for a Youth Guarantee and Socialist Party campaigns against the JobBridge labour market internship programme (Scambridge, 2014). The winding down of social partnership has left some 
trade union interests weakened by the loss of associated policy mechanisms; however, they retain some institutional and campaigning capacity to influence activation, as does civil society. On the other hand international and domestic business interests are increasingly visible and vocal. Media interests maintain a dominant neo-liberal frame in commenting on the crisis (Mercille, 2014) and also engage in a socially constructed fraud discourse that differentiates the welfare-dependent population from the taxpaying population (NESC, 2011).

Policy making has thus become a more elite process. Opponents who might develop political coalitions against 'work-first activation' have been weakened, politically excluded and their advocacy has been limited by new funding regimes (Harvey, 2014). Groups most impacted by activation are electorally weak but have built active coalitions and found some political voice. Young people have campaigned against internships and precarious work through 'We're Not Leaving' (2014). Lone parents in the Seven is too Young campaign partially resisted welfare conditionality for lone parents whose youngest child is aged seven or over, restricting full conditionality to lone parents whose youngest child is 14 or over (Murphy and Loftus, 2015). Trade unions have primarily focused on presenting members' interests in the context of public sector mergers. However, alongside non-governmental organisations (NGOs) they also publically opposed or critiqued various ALMPs (including JobBridge, Gateway and TUS) but have had little impact on policy. Despite considerable disquiet on the ground, there was limited meaningful contestation of Irish activation policy in the 2015 government-initiated National Economic Dialogue or the October 2015 Patbways to Work consultation process. With exceptions (Boland and Griffin, 2015; EAPN Ireland, 2015; INOU, 2015; Murphy and Loftus, 2015) there has been little critical focus on the sanctions regime or notable campaigns against Patbways to Work.

\section{Ideational}

Table 1 outlines key ideological systems that inform approaches to activation. The table suggests a neo-liberal frame might accommodate low pay, privatisation and new managerialism, a conservative frame might stress the imperative of control including fiscal, fraud and behavioural or social regulation, and a social democratic frame might champion full employment, equality and decent work. Our interest is in which frames dominate and why. In the mid to late crisis period we expect a strong neo-liberal frame from international actors including the EU and OECD, but also ideational framing influenced by a Christian Democratic dominated government (FG) as well as some counter-balancing social democratic framing from the minor social democrat coalition partner (LP). Before examining the ideological orientation of Irish activation policy we first explore the international ideational sources for Irish activation policy. 
Table 1. Indicators of ideological influences.

\begin{tabular}{llll}
\hline Ideology/indicator & 1 & 2 & 3 \\
\hline Neo-liberal & Low wages & Privatisation & New Public Managerialism \\
Conservative & Fiscal control & Fraud control & Behavioural control \\
Social Democratic & Full employment & Equality & Decent work \\
\hline
\end{tabular}

While the practical influence of the Troika and the ideational influence of the OECD are crucial variables influencing change, it is important not to underplay the role of domestic elites or overlook the mutual interaction between the domestic and international ideational processes. Domestic policy actors actively translate international ideas and ideologies into domestic activation policy and discourse, filtering and selectively amplifying different aspects of policy (Murphy, 2012a). The standing down of domestic social partnership diminished the role of various domestic cognitive institutions and lessened the influence of traditional indigenous ideational sources. The recent lack of impact of the National Economic and Social Council (NESC) on activation policy can be contrasted with the role NESC played in framing responses in the 1980s crisis (Ireland, 1987; NESC, 1986, 2011). The National Economic and Social Forum, an indigenous labour market policy entrepreneur in the 1990s (NESF, 1994) was an early casualty of the crisis. Other rights and equality ideational champions were badly damaged over the crisis (Harvey, 2014).

Pre-crisis, the cognitive influences of the EES were only loosely translated into the NEAP and the historical impact of Europeanisation was not as great as might have been expected (Murphy, 2012b; Van Vliet and Koster, 2008). During the crisis, both domestic politics and international ideational actors influenced activation policy. Troika and OECD influence overlapped and Europeanisation is clearly evident. Irish euro membership shaped macroeconomic parameters and determined Irish responses to the crisis and this informed the context in which the Troika MOU became the blueprint for managing the crisis. Policy transfer is a complex process, especially in the context of path dependency. International ideational actors are evident in key policy documents. OECD policy entrepreneurs Grubb et al. (2009), Martin (2010) and Gonzalez Pandiella (2013) and UK policy consultant Finn (2011) all left policy footprints; US and Australian models also influenced key proposals (DSP, 2011, 2014b). However, interaction between the domestic and international is two-way. The Troika MOU activation blueprint reflected the recommendations of the Irish government-commissioned OECD review of Irish activation (Grubb et al., 2009); crucially this had also influenced the indigenous National Recovery Plan for 2011-2014 (Ireland, 2011a). While the EU shaped the new Youth Guarantee, the 2013 Irish presidency shaped 
EU policy on the Youth Guarantee. Finer details of the Youth Guarantee (DSP, 2014a) were in turn shaped by an Irish government-commissioned report from the OECD (2014). We proceed to unpack the framework in Table 1 to examine which international and domestic ideas dominated and steered recent Irish activation policy choices and outcomes.

Low pay has long been a feature of the Irish economy. However, wages have declined over the crisis and precarious working conditions have intensified (Murphy and Loftus, 2015; NERI, 2015; O'Sullivan et al., 2015). The work-first Irish activation model accepts low pay as the starting point for activation. Policy reinforces the sustainability of low-paid jobs by commodifying and pressuring people to accept such jobs and by making available in-work benefits to top up low wages. Policy assumes that any job has better consequences than unemployment even if this is contradicted by evidence that precarious work can impact negatively on mental and physical health. Boland and Griffin (2015: 15) describe a 'harsh, unsympathetic and authoritarian' policy - which ultimately 'makes people accept work at lower wages or in worse conditions ... guaranteeing employers a ready pool of labour and alleviating pressure on employers to offer good conditions or competitive wages' - an outcome they describe as 'unjust and morally repugnant' (p. 22). 30.3 per cent of Irish employees (400,000 workers) lie below the low pay threshold of $€ 12.20$ per hour, with women representing 60 per cent of all those who are low paid (NERI, 2015). 87 per cent of the low paid are in the private sector, with one-quarter in the wholesale and retail sector and almost one in six in the accommodation and food sector. Reflecting campaigns against low pay, following recommendations by a Low Pay Commission (LPC) established in late 2014 , the Irish minimum wage will increase from the pre-crisis rate of $€ 8.65$ per hour to $€ 9.15$ per hour in 2016 (LPC, 2015). The LPC has also signalled intent to reform labour protections to protect against exploitative 'if and when' contracts, the Irish version of zero-hour contracts (O'Sullivan et al., 2015).

New Public Management culture and practice is now a dominant feature of Irish activation and guides its implementation. The use of profiling tools to determine PEX (Probability of Exit) means less discretion, more automated decision processes and less room for building trust in claimantmediator relationships. Information technology-driven bureaucratic processes control the process of client engagement; form filling and administration take proportionally more of the workers' time and institutional needs increasingly dominate the mediation process (Creedon, 2014). Consistent with activation practice elsewhere, managerialism shifts power at street level (Lipsky, 2013). The privatisation process will contribute to what Brodkin (2015: 6) describes as a culture of 'meeting the numbers', where staff workloads become dominated by targets and key performance indicators (Lowe, 2015).

Privatisation is a common feature of neo-liberal practice. PES capacity and skill deficits had been a feature of the 1980s crisis but the challenge was 
met through investing in not-for-profit NGOs in a new Local Employment Service (NESF, 1994). With public expenditure constrained by the terms of the 2011 Fiscal Treaty, the Irish state this time addressed PES capacity and skills deficits through privatisation of employment services for the long-term unemployed. While partially motivated by the need to address genuine shortto medium-term temporary capacity issues, there is also a strong ideological orientation to privatisation amongst key domestic actors including advisors in the Taoiseach's policy unit. Under Patbways to Work (DSP, 2014b) in October 2014 the DSP, following a tendering process supported by the London-based Centre for Economic and Social Inclusion, contracted two private companies to deliver JobPath. These will in turn subcontract local and specialised Irish NGOs. This new activation programme for Ireland's long-term unemployed will have significant implications. Statutory agencies (and unionised workers) are more likely to resist punitive behavioural sanctions and less likely to have work performance patterned by metrics. Private agencies paid by results are more likely to control and manipulate claimants and outcomes (Brodkin, 2013; Wiggan, 2015). The Irish model of privatisation relies less on the primacy of market rationality and has more regulation of standards and moderation of provider empowerment than the British model (Lowe, 2015). Wiggan (2015: 162) attributes this to LP presence in the social protection ministry and their 'core preference for protecting equity and retaining state involvement in welfare provision'.

Fiscal controls now dominate public policy in Ireland. The combination of Troika reporting schedules and European Semester fiscal treaty deficit reduction targets steers and controls Irish budgetary policy. A traditional focus on expenditure control is now intensified in the Department of Public Expenditure and Reform's focus on value for money. The politics of activation also plays out between political and bureaucratic powers in government departments: fiscal targets mean the senior civil service manager's power is enhanced. The presence of penalties and sanctions is also related to fiscal control. Even the presence of sanctions reduces the claimant count (Finn, 2011) and it is difficult to separate political imperative to reduce unemployment from the drive to control costs and manage budgets. The latent fiscal function of sanctions is as important as the more manifest labour market behavioural functions (Brodkin, 2013).

Fraud control overlaps with behavioural and fiscal control agendas. The fraud control agenda is directly linked to expenditure controls in that fraud savings targets are directly built into government budgetary targets. Likewise, there is significant overlap with the narratives of behavioural and fraud control. These combine to create a climate of distrust in social welfare recipients (Boland and Griffin, 2015). Two activation programmes, TUS and Gateway, embed fraud control in the activation processes targeting a particular cohort of the long-term unemployed considered at high risk of fraud and offer 
activation programmes with the primary objective of mitigating fraud. The quasi-activation process is managed by a senior civil servant who has a parallel fraud control role in the DSP. Language matters in public discourse and can valorise some citizens over others (Abowitz and Hannish, 2006). Irish policy discourse increasingly uses managerial or conservative discourse reflecting a moral undertone about joblessness, welfare dependency and lifestyle choices and an alarmist and disproportionate fraud discourse (NESC, 2011).

Behavioural controls are a relatively new focus of Irish activation policy which was previously characterised by a supportive and sensitive rhetoric (NESC, 2011) reflecting successive Irish governments' reluctance to apply benefit sanctions to job seekers (Grubb et al., 2009). Over 2011 to 2015 legal reforms targeted new penalties towards unemployed job seekers, lone parents and young people. The Social Welfare Act 2010 provided that, from April 2011, payment can be reduced by $€ 44$ per week if an adult job seeker refuses an appropriate offer of training, declines an intervention, does not attend meetings, or drops out of the process. From July 2013 those on the penalty rate of $€ 144$ for 21 days or more can be disqualified from receiving job seeker payments for up to nine weeks, or in extreme cases receive a total ban. From July 2015 job seekers are penalised for failure to upload a CV on a government website. Due to pressure to report to the Troika, the number of penalties rose considerably: from March to December 2011 there were 359 penalties issued, in 2012 the number of penalties rose to 1,500, in 2013 penalties increased to 3,500 and 2014 saw 6,500 penalties issued.

It is not clear how this new sanctions regime will embed in a culture that has traditionally resisted the application of sanctions (Martin, 2014). While only a relatively low 1 per cent of the job seeker population so far has received penalties, it is impossible to gauge whether this might increase in future years. There is evidence that sanctions are unpopular and their use is mitigated in practice by many PES staff. However, Lowe (2015) observes that JobPath's pay-by-results regime requires staff to wield the sanctions stick effectively in order to ensure that clients search for work effectively. In 2017 JobPath will also apply conditionality to people in part-time employment and in receipt of in-work benefits. Young people are required to have a higher level of engagement and commitment with PES, and the roll-out of the Youth Guarantee will likely increase sanctions for young people under 25. It is also notable that Ireland has not yet achieved a 'triple integration' where activation sits alongside 'unemployment support homogenisation' and 'unemployment policy co-ordination' (Clasen and Clegg, 2011). In 2010 DSP proposed unemployment support homogenisation in the form of a Single Working Age Payment where labour market conditionality would be applied, on the same basis as for unemployment payments, to lone parents, partners/spouses, people with disabilities and carers (Martin, 2011). Most of these proposals were quietly shelved, although in 2015 government proceeded with a new sanction regime 
for lone parents whose youngest child is 14 years of age or older (Murphy and Loftus, 2015), and a growth led activation strategy will likely expand sanctions to other groups.

Full employment: high levels of labour market participation are a social democratic imperative and are an underlying objective of Nordic high-road activation policy which aims to both lower unemployment and achieve full employment. From 2007 to 2013 'economic inactivity' rose from 27.5 per cent to 30.5 per cent (NERI, 2015) and the 2013 employment rate of 65.5 per cent is below the European Union and Eurozone average of 68.4 per cent. Taking into account 139,300 underemployed workers, 23.5 per cent of the Irish labour force were either unemployed or underemployed in Q3 2013 (O'Farrell, 2013). Low pay is clearly related to low hours of work, part-time work and temporary contracts or more general precarious working conditions; the in-work poverty rate for part-time workers is more than twice that for full-time workers and much male part-time employment is involuntary. The labour market and related activation policy remain gendered. Along with Spain, the Netherlands and the UK, Ireland's historic 'male bread-winner state has continued into the activation age' with little investment in childcare (Rice, 2015:190).

Decent jobs are a hallmark of social democratic activation. Post-crisis government dismantled labour legislation and decreased minimum wages. Since 2011 some of these changes including the minimum wage cut were restored. Nonetheless, the Irish labour market is relatively precarious with very flexible hiring and firing practices leading to a condition of flex-insecurity for Ireland's vulnerable workforce, particularly women, young people and migrants (Murphy and Loftus, 2015; O’Sullivan et al., 2015). The proportion of men working part-time more than doubled from its pre-crisis level of 7.1 per cent in Q4 2006, to 16.8 per cent by Q4 2012, while the proportion of women working part-time has increased from an already high level of 31.1 per cent to 35.8 per cent over the same period (NERI, 2015). Full-time employment had steadily declined, from 70 per cent working 35 hours or more in 2001, to just 60 per cent in 2011. However, it is noticeable that in 2015 the labour market experienced significant full-time job growth with a related decline in the number of part-time jobs (CSO, 2015).

Equality is a core social democratic value as is the concept of an inclusive labour market but Patbways to Work is notable for its lack of consideration of equality (INOU, 2015). The activation strategy does little to address the barriers to work for people with disabilities. Ireland maintains an absolute ban on asylum seekers working. EAPN Ireland (2015: 1) critiqued the Irish model of activation and stressed the need to support people to live in dignity and participate in society, whether in or out of work. Rice (2015) questions the degree to which activation can transform pre-existing structures of socio-economic equality. Without reforming the structure and quality of jobs and addressing childcare, women will be activated into a male labour market 
(Murphy and Loftus, 2015). While in 2015, on the one hand, the LPC is examining mechanisms to address the disproportionate number of women in low-paid employment, on the other hand, since July 2015 lone parents, once their youngest child is 14 , are subject to activation into full-time jobs and with reduced in-work benefits.

\section{Conclusion}

What and who are driving Irish activation policy? The political momentum behind this 'work-first' activation model and the control, managerial and privatisation agendas informing its practical delivery include both domestic and international drivers. The OECD provided the blueprint that was mediated into Irish policy through domestic elites. Martin (2014: 17) is clear that the 'radical' shift in Irish activation policy was formulated in Grubb et al.'s (2009) OECD review of Irish activation and adopted by domestic policy actors before it was subsequently written into the Troika programme. However, the Troika programme was crucial to its implementation. The support and conditionality framework in the MOU required a schedule of reform of the benefits system to create greater incentives to take up employment and to tighten eligibility and means-test criteria (Hardiman and Regan, 2012: 12). The revised versions of the MOU stressed implementation with clear targets for PES institutional reform alongside a quarterly reporting system for implementing an enhanced sanctions regime. The Troika's presence was crucial. They determined the speed of the reform agenda even if some policy and implementation mechanisms were the choice of the government (Weymes, 2012: 8). The presence of the Troika also provided the political imperative to remove vetoes and ensure that the implementation proceeded without derailment. The OECD/Troika MOU influence has been stronger than previous cognitive Europeanisation processes associated with the EES and OMC. Postcrisis, euro members are now governed through the European Semester process. Country-specific recommendations on labour market policy will likely intensify the influence of European governance processes.

The impact of domestic politics is also visible. Government parties have adopted neo-liberal low-road approaches which assume that any job is better than none, that low wages are acceptable and also promote privatisation and managerial approaches to manage the 'stock' of unemployment. Conservative ideologies feature and centre on various aspects of control, not least fiscal control but also fraud and behavioural controls, which tend to demonise the unemployed and single out lone parents. Social democratic logics are evident in the restoration of minimum wages and some labour protections as well as in the chosen model for employment services privatisation. Other social democratic imperatives, in particular equality, universal services, decent jobs and 
high participation are less visible or influential. Ireland was a slow moderniser in adopting such supply-side fundamentalism but crisis has occasioned a significant shift in the orientation of Irish policy. As Bonoli (2013) anticipated, as a laggard Ireland has less institutional stickiness and adapted rapidly in the context of aid conditionality. Ireland's experiment with marketisation and modernisation is leading towards quick convergence to European norms (Van Berkel et al., 2012). The impact of privatisation is potentially very significant, opening the likelihood of greater managerialism.

The future is not yet clear but may mean profound shifts in rights and the concept of citizenship as well as shifts in power from both the state and nonprofit sectors towards market actors. Clasen and Clegg (2011) contrast countries in which policy adaptation has been constrained, hesitant and uneven to countries where activation policies are part of an unambiguous adaptation of labour market policies to the emergent post-industrial economy. Ireland was clearly part of the former hesitant group. Failure to achieve unemployment support homogenisation suggests ongoing adaptation will be ambiguous and uneven. The departure of the Troika makes domestic politics and tensions more visible and there are challenges for domestic politics in managing the post-Troika stages of reform. Thus far the Irish government, consistent with liberal states, is imposing policy rather than negotiating change through compromise. While the domestic agenda appears most driven by the powerful Christian Democratic led Department of an Taoiseach, the more minor social democratic partner is consistently on message with the 'work-first' philosophy. With these parties in power the control and sanctions driven agenda seems likely to intensify. However, activation also appears to be the only game in town. While many are critical of aspects of the policy, beyond rhetoric few alternative approaches are championed (Ingold and Etherington, 2014). While a 2016 General Election may shift power, it is not clear how a new combination of political forces might shift the fundamental direction of activation policy. With unemployment just below 9 per cent and only one job vacancy for every 15 unemployed people, the issue to be resolved is still one of demand (NERI, 2015). As Grover (2009) has argued, governments need to focus less on supply and more on demand-side factors, on the quality of the jobs created, and on the barriers and discrimination people face when trying to access them. The Action Plan for Jobs (DJEI, 2015) has, to date, failed to focus on the quality of work and only in 2015 began to address the spatial distribution of employment. The Irish Low Pay Commission is an important initiative but needs stronger powers if it is to fulfil the uphill task of combating precarious working conditions and promoting decent work (ICTU, 2015).

\section{Funding}

This research received no specific grant from any funding agency in the public, commercial, or not-for-profit sectors. 


\section{References}

Abowitz K and Hannish J (2006) 'Contemporary Discourse on Citizenship', Review of Educational Research 76(4): 653-690.

Armingeon K (2007) 'Active Labour Market Policy, International Organizations and Domestic Politics', Journal of European Public Policy 14(6): 905-932.

Bengtsson M (2014) 'Towards Standby-ability: Swedish and Danish Activation Policies in Flux', International Journal of Social Welfare 23: 54-70.

Boland T and Griffin R (2015) The Condition of Unemployment: Appraising the Impact of Ireland's New Welfare Policies. Waterford: Waterford Institute of Technology.

Bonoli G (2013) The Origins of Active Social Policy: Labour Market and Childcare Policies in a Comparative Perspective. Oxford: Oxford University Press.

Boyle N (2005) FÁS and Active Labour Market Policy, 1985-2004. Studies in Public Policy 17. Dublin: The Policy Institute, Trinity College Dublin.

Brodkin EZ (2013) 'Street-Level Organizations and the Welfare State', in EZ Brodkin and G Marston (eds) Work and the Welfare State: Street-Level Organizations and Workfare Politics. Washington DC: Georgetown University Press.

Brodkin EZ (2015) 'Street-Level Organizations and the "Real World" of Workfare: Lessons from the US', Social Work E Society 13(1): 1-16.

Brodkin EZ and Marston G (eds) (2013) Work and the Welfare State: Street-Level Organizations and Workfare Politics. Washington DC: Georgetown University Press.

Central Statistics Office (CSO) (2014) 'Population and Migration Estimates April 2014'. Dublin: CSO.

Central Statistics Office (2015) 'Quarterly National Household Survey for Quarter 3, 2015'. Dublin: CSO.

Clasen J and Clegg D (eds) (2011) Regulating the Risk of Unemployment: National Adaptations to Post-industrial Labour Markets in Europe. Oxford: Oxford University Press.

Clasen J, Clegg D and Kvist J (2012) 'European Labour Markets in (the) Crisis', Working Paper 2012:12. Brussels: ETUI.

Creedon M (2014) 'Some Thoughts on Activation', paper for Irish Activation Policy and Practice, seminar, 22 September, Maynooth University.

Darmon I and Perez C (2010) "'Conduct of Conduct" or the Shaping of Adequate Dispositions? Labour Market and Career Guidance in Four European Countries', Critical Social Policy 31(1): 77-101.

De la Porte C and Pochet P (2012) 'Why and How (Still) Study the Open Method of Co-ordination (OMC)?', Journal of European Social Policy 22(3): 336-349.

Department of Jobs, Enterprise and Innovation (DJEI) (2015) Action Plan for Jobs. Dublin: DJEI.

Department of Social Protection (DSP) (2011) Pathways to Work. Dublin: DSP.

Department of Social Protection (2013) 'Briefing for the Lone Parents'. Dublin: DSP.

Department of Social Protection (2014a) Ireland Youth Guarantee. Dublin: DSP. Department of Social Protection (2014b) Patbways to Work 2015. Dublin: DSP. 
EAPN Ireland (2015) 'Position Paper on Irish Activation: July 2015'. Dublin: European Anti-Poverty Network Ireland.

Finn D (2011) 'An International Overview to Supports and Services for Unemployed Job Seekers', paper for Challenges and Opportunities in a Time of Recession, 15 September, Royal Irish Academy, Dublin.

Forfás (2010) Review of Labour Market Programmes. Dublin: Department of Enterprise, Trade and Employment.

Gonzalez Pandiella A (2013) 'Getting Irish Youth on the Job Track', Economics Department Working Papers No. 1101 (Eco/Wkp (2013) 93). Paris: OECD.

Grover C (2009) 'Privatising Employment Services in Britain', Critical Social Policy 29(3): 487-509.

Grubb D, Singh S and Tergeist P (2009) 'Activation Policies in Ireland', OECD Social, Employment and Migration Working Papers No. 75. Paris: OECD.

Hacker JS (2004) 'Privatizing Risk without Privatizing the Welfare State: The Hidden Politics of Social Policy Retrenchment in the United States', American Political Science Review 2(98): 243-260.

Hall P and Taylor R (1996) 'Political Science: The Three New Institutionalisms', Political Studies XLIV: 936-957.

Hardiman N and Regan A (2012) 'The Politics of Austerity in Ireland', Intereconomics 48(I): 9-13.

Harmon C, Morrin P and Murphy S (2012) 'Issues on the Evaluation of Revised Employment Action Plan/NEES' [http://www.welfare.ie/en/downloads/Issueson-the-Evaluation-of-Revised-Employment-Action-Plan_N.pdf], accessed 24 June 2013.

Harvey B (2014) 'Are We Paying for That?': Government Funding and Social Justice Advocacy. Dublin: The Advocacy Initiative.

Hay C (2004) 'Ideas, Interests and Institutions in the Comparative Economy of Great Transformations', Review of International Political Economy 2(1): 204-226.

Heidenreich M and Graziano PR (2014) 'Lost in Activation? The Governance of Activation Policies in Europe', International Journal of Social Welfare 23: 15-25.

Huber E and Stephens J (eds) (2001) Development and Crisis of the Welfare State and Policies in Global Markets. Chicago: Chicago University Press.

ICTU (2015) Legal Observations on the Low Pay Commission Heads of Bill, Irish Congress of Trade Unions [http://www.ictu.ie/download/pdf/low_pay_commission_submission_march_2015.pdf].

Ingold J and Etherington D (2014) 'Work, Welfare and Gender Inequalities: An Analysis of Activation Strategies for Partnered Women in the UK, Australia and Denmark', Work, Employment and Society 27(4): 621-638.

INOU (2015) 'Sharing in the Recovery: Budget 2016'. Dublin: Irish National Organisation of the Unemployed.

Ireland (1987) Programme for National Recovery. Dublin: Stationery Office.

Ireland (2010) 'Memorandum of Understanding'. Dublin: Stationery Office.

Ireland (2011a) National Recovery Programme 2011-2014. Dublin: Stationery Office. 
Ireland (2011b) Programme for Government 2011-2016. Dublin: Stationery Office.

Kirby P and Murphy MP (2011) Towards a Second Republic: Irish Politics after the Celtic Tiger. London: Pluto Press.

Labour Market Council (2014) Interim Report of the Labour Market Council. Dublin: Stationery Office.

Lipsky M (2013) 'The American Welfare State: Two Narratives', in EZ Brodkin and G Marston (eds) Work and the Welfare State: Street-Level Organizations and Workfare Politics. Washington DC: Georgetown University Press.

Lødemel I and Moreira A (2014) Activation or Workfare? Governance and Neo-liberal Convergence. Oxford: Oxford University Press.

Lowe S (2015) 'JobPath: The Proposed Introduction of an Employment Programme in the Republic of Ireland', pp 113-130 in The Public Sphere. London: LSE.

Low Pay Commission (LPC) (2015) Recommendations for the National Minimum Wage. LPC Report No. 1, July 2015. Dublin: Low Pay Commission [http://www.lowpaycommission.ie/publications/national-minimum-wage-/recommendations-ofthe-low-pay-commission-for-the-national-minimum-wage-2015-.pdf].

McGuinness S, O'Connell PJ, Kelly E and Walsh JR (2011) Activation in Ireland: An Evaluation of the National Employment Action Plan. Research Series No. 20. Dublin: ESRI.

Martin J (2011) 'Single Social Assistance Payment for People of Working Age', Presentation to Department of Social Protection consultation seminar Progression to a Single Working Age Payment, 10 July, Goldsmith House, Dublin.

Martin J (2014) 'Activation and Active Labour Market Policies in OECD Countries: Stylized Facts and Evidence on their Effectiveness', Geary Paper 6/2014 WP2014/09. Geary Institute, University College Dublin.

Mercille J (2014) The Political Economy and Media Coverage of the European Economic Crisis: The Case of Ireland. London: Routledge.

Murphy MP (2012a) 'Interests, Institutions and Ideas: Explaining Irish Social Security Policy', Policy and Politics 40(3): 347-365.

Murphy MP (2012b) 'The Politics of Irish Labour Activation: 1980-2010', Administration 60(2): 27-49.

Murphy MP and Loftus C (2015) 'A Precarious Future: An Irish Example of FlexInsecurity', pp. 98-117 in S Riain, F Behling, R Ciccia and E Flaherty (eds) The Changing Worlds and Workplaces of Capitalism. London: Palgrave.

NERI (2015) 'Quarterly Economic Facts, December 2015'. Dublin: Nevin Economic Research Institute.

NESC (1986) A Strategy for Development: Growth, Employment and Fiscal Balance. Dublin: Stationery Office.

NESC (2011) Supports and Services for Unemployed Jobseekers: Challenges and Opportunities in a Time of Recession. Report No. 123. Dublin: National Economic and Social Council.

NESC (2013) Activation Report No. 8. Dublin: NESC.

NESF (1994) Ending Long-term Unemployment: Forum Report No. 4. Dublin: National Economic and Social Forum. 
OECD (Organization for Economic Cooperation and Development) (2014) Ireland: Implementing a Youth Guarantee. Paris: OECD.

O'Farrell R (2013) 'The Polarisation of Working Hours in Ireland', NERI WP 9. Dublin: NERI.

Oireachtas Committee on Jobs, Social Protection and Activation (2015) 'Debate on Activation' [http://oireachtasdebates.oireachtas.ie/Debatespercent20Authoring/DebatesWebPack.nsf/committeetakes/EDJ2015021800002?opendocument\#K00100].

O'Sullivan M et al. (2015) A Study on the Prevalence of Zero Hours Contracts among Irish Employers and their Impact on Employees. Dublin: Low Pay Commission/University of Limerick.

Peck J and Theodore N (2000) 'Beyond "Employability", Cambridge Journal of Economics 24(6): 729-749.

Rice D (2015) 'Applying Welfare Regimes in Empirical Analysis: The Example of Activation', pp. 171-198 in Z Irving, M Fenger and J Hudson (eds) Social Policy Review 27.

Scambridge (2014) [http://www.scambridge.ie/].

Tsebelis G (2002) Veto Players: How Political Institutions Work. New York/Princeton: Russell Sage Foundation/Princeton University Press.

Van Berkel HHA, de Graaf W and Sirovatka T (2012) 'Governance of the Activation Policies in Europe: Introduction', International Journal of Sociology and Social Policy 32(5/6): 260-272.

Van Gerven M, Vanhercke B and Gürocak S (2014) 'Policy Learning, Aid Conditionality or Domestic Politics? The Europeanization of Dutch and Spanish Activation Politics through the European Social Fund', Journal of European Public Policy 21(4): 509-527.

Van Vliet O and Koster F (2008) 'Europeanization and the Political Economy of Active Labour Market Policies', Paper for the NIG Annual Work Conference 2008. Panel 11: The EU as a Transformative Force, 20-21 November, Enschede.

We're Not Leaving (2014) [http://werenotleaving.com/category/precarious-workinternships/].

Weymes L (2012) 'Fiscal Consolidation: Does it Deliver?', Economics Letters Series Vol. 7. Dublin: Central Bank.

Wiggan J (2015) 'What Variety of Employment Service Quasi-Market? Ireland's JobPath as a Private Power Market', pp. 151-165 in Z Irving, M Fenger and J Hudson (eds) Social Policy Review 27.

\section{Author biography}

Mary P. Murphy is a lecturer in Irish Politics and Society in the Department of Sociology, Maynooth University in Ireland. She has research interests in gender and social security, globalisation and welfare states, activation, the politics of redistribution and power and civil society. She has published widely, most recently Careless to Careful Activation: Making Activation Work for Women (Dublin NWCI, 2012) and Towards a Second Republic: Irish Politics after the Celtic Tiger (with Peadar Kirby, Pluto Ireland, 2011). In 2014 she was appointed a part-time commissioner with the Irish Human Rights and Equality Commission and is an active advocate for social justice and gender equality. 